\title{
Pengaruh Kepuasan Kerja terhadap Komitmen Organisasional Karyawan pada Organisasi Kantor Hukum
}

\author{
Priskilla Nahita \\ Program Studi Sekolah Manajemen Bisnis, Sekolah Tinggi Manajemen PPM \\ Jl. Menteng Raya No.9, Kb. Sirih, Kec. Menteng, Kota Jakarta Pusat, Jakarta, Indonesia \\ priskillanahita@gmail.com \\ Eva Hotnaidah Saragih* \\ Program Studi Sekolah Manajemen Bisnis, Sekolah Tinggi Manajemen PPM \\ Jl. Menteng Raya No.9, Kb. Sirih, Kec. Menteng, Kota Jakarta Pusat, Jakarta, Indonesia \\ evasaragih67@gmail.com
}

Diterima: 09-02-2021

Disetujui: 16-06-2021

Dipublikasi: 30-06-2021

\begin{abstract}
ABSTRAK
Dari hasil studi literatur, belum ditemukan penelitian yang menguji pengaruh kepuasan kerja terhadap komitmen karyawan pada organisasi yang bergerak di bidang kantor hukum, khususnya pada konteks Jakarta, Indonesia. Umumnya penelitian dilakukan pada organisasi bisnis atau organisasi pemerintahan. Sedangkan pengelolaan sebuah kantor hukum berbeda dengan pengelolaan organisasi bisnis maupun pemerintahan. Perlu diketahui bagaimana sebaiknya organisasi di bidang hukum mengelola dan memperlakukan karyawannya, agar mereka memiliki kepuasan dan komitmen yang tinggi terhadap pencapaian sasaran organisasi. Apakah pendekatan manajemen sumberdaya manusia yang sebaiknya dilakukan sama atau berbeda dengan yang diterapkan pada jenis organisasi lainnya. Dengan demikian penelitian ini bertujuan untuk: (1) Menguji secara kuantitatif pengaruh kepuasan kerja terhadap komitmen karyawan pada organisasi yang bergerak di bidang Kantor Hukum, (2) Mengidentifikasi tingkat kepuasan kerja dan komitmen karyawan pada organisasi Kantor Hukum yang menjadi obyek studi dan faktor-faktor yang dominan membentuk kepuasan kerja serta komitmen yang tinggi dari karyawan, dan (3) Menetapkan implikasi teoritis dan manajerial berdasarkan temuan yang didapat pada tujuan penelitian pertama dan kedua. Penelitian dilaksanakan menggunakan metode penelitian kuantitatif melalui analisis regresi sederhana. Teknik pengumpulan data dilakukan dengan menyebarkan kuesioner kepada 153 (seratus lima puluh tiga) responden dari sebuah kantor hukum yang berlokasi di Jakarta Indonesia. Hasil penelitian menunjukkan bahwa kepuasan kerja berpengaruh positif secara signifikan terhadap komitmen organisasional karyawan. Penelitian ini juga menemukan tiga dimensi kepuasan kerja yang mendapat penilaian tinggi sehingga membuat angka kepuasan kerja secara keseluruhan dikategorikan sangat baik. Keempat dimensi tersebut secara berurutan adalah: penghargaan dari perusahaan, rekan kerja dan sifat pekerjaan.
\end{abstract}

\section{Kata Kunci:}

Kepuasan Kerja; Komitmen Organisasional; Kantor Hukum; Penghargaan dari Perusahaan; Rekan Kerja; Sifat Pekerjaan.

\begin{abstract}
From the literature studies, research has not been found that examines the effect of job satisfaction on employee commitment in organizations engaged in law firms, especially in the context of Jakarta, Indonesia. Generally, research is carried out in business organizations or government organizations. Meanwhile, managing a law office is different from managing a business or government organization. It is necessary to know how best an organization in the legal field should manage and treat its employees, so that they have high satisfaction and commitment to achieving organizational goals. Whether the approach to human resource management should be the same or different from that applied to other types of organizations. Thus this study aims to: (1) quantitatively examine the effect of job satisfaction on employee commitment in organizations engaged in the Law Office, (2)
\end{abstract}


Identify the level of job satisfaction and employee commitment to the Law Office organization which is the object of study and the factors dominant forms of job satisfaction and high commitment from employees, and (3) Establishing theoretical and managerial implications based on the findings obtained in the first and second research objectives. The research was conducted using quantitative research methods through simple regression analysis. The data collection technique was carried out by distributing questionnaires to 153 (one hundred and fiftythree) respondents from a law office located in Jakarta, Indonesia. The results showed that job satisfaction had a significant positive effect on employee organizational commitment. This study also found three dimensions of job satisfaction that received high ratings so that the overall job satisfaction rate was categorized as very good. The four dimensions are sequentially: appreciation from the company, colleagues and the nature of the job.

Keywords:

Job Satisfaction; Organizational Commitment; Law office; Appreciation from the Company; Colleagues; Nature of the Job. 


\section{PENDAHULUAN}

Menurut Robbins \& Judge (2012), komitmen organisasional memiliki definisi yaitu sampai dimana tingkat seorang karyawan memihak pada suatu organisasi tersebut. Hal ini sejalan dengan pernyataan Stup (2006) yang mengemukakan bahwa komitmen terhadap organisasi adalah kekuatan relatif dari keterikatan atau keterlibatan karyawan dalam organisasi tempatnya bekerja. Komitmen yang kuat memungkinkan setiap karyawan untuk berusaha menghadapi tantangan dan tekanan yang ada. Sebelumnya Matthews dan Shepherd (2002) menyebutkan karyawan yang memiliki komitmen terhadap organisasi tempat ia bekerja, memiliki keyakinan dan penerimaan yang kuat terhadap sasaran dan nilainilai yang dimiliki organisasi, menunjukkan kemauan untuk mengeluarkan usaha yang dapat diperhitungkan bagi organisasi, dan memiliki keinginan yang kuat untuk mempertahankan keanggotaan dalam organisasi. Komitmen terhadap organisasi menjadi penting karena kecil kemungkinan karyawan yang memiliki komitmen pergi meninggalkan organisasi untuk mencari pekerjaan lain dan biasanya juga mereka menghasilkan kinerja yang tinggi. Saat ini, metode yang paling banyak digunakan untuk mempelajari konsep ini adalah dengan mengetahui pandangan karyawan melalui sikap dan perasaan yang diberikan terhadap organisasi tempat mereka bekerja.

Terdapat banyak faktor yang mempengaruhi komitmen organisasional karyawan, salah satunya adalah kepuasan kerja. Telah cukup banyak penelitian yang dilakukan menemukan bahwa kepuasan kerja berkorelasi dan memiliki pengaruh positif terhadap komitmen organisasional (Bashir \& Gani, 2019; Eliyana, Ma'arif \& Muzakki, 2019; Dalkrani \& Dimitriadis, 2018; Shah et al, 2014; Imam, Raza \& Ahmed, 2014). Komitmen organisasional dipengaruhi oleh sejauh mana pekerjaan dan organisasi dapat memberikan kepuasan terhadap karyawan. Maka dari itu, setiap pengelola organisasi dituntut untuk secara fokus mencermati betapa pentingnya pemahaman dan pemenuhan kepuasan kerja karyawan (Robbins \& Judge, 2012).

Menurut Hellriegel \& Slocum (2011) kepuasan kerja menunjukkan hasil pengalaman kerja dan tingkat kekecewaan dalam upaya menunjukkannya pada perusahaan atau organisasi mana saja yang butuh perhatian. Jika karyawan merasa tidak puas atau kecewa pada perusahaan atau organisasi, keterlibatannya juga menjadi berkurang karena komitmen pada organisasi yang rendah yang selanjutnya muncul hal-hal negatif yang akan menghambat keberlangsungan pembangunan organisasi atau perusahaan. Apabila dalam lingkungan kerja seorang karyawan tidak mendapatkan apa yang diharapkan, diantaranya peluang promosi yang adil, pendapatan yang baik, rekan kerja, dan atasan yang menyenangkan serta kepuasan terhadap pekerjaan itu sendiri maka dapat dipastikan komitmen karyawan terhadap organisasi akan rendah.

Robbins \& Judge (2012) mengatakan bahwa kepuasan kerja adalah suatu sikap umum terhadap pekerjaan seseorang sebagai perbedaan antara banyaknya ganjaran yang diterima pekerja dan banyaknya yang diyakini yang seharusnya diterima. Banyak faktor dimana karyawan merasa tidak puas dengan organisasi atau perusahaan tempat mereka bekerja, contohnya seperti kemampuan mereka yang kurang optimal dimanfaatkan, kurang mendapat tanggapan jika mereka sudah melakukan pekerjaan 
dengan baik, atasan juga rekan kerja. Hal ini mengisyaratkan bahwa kepuasan kerja sangat penting bagi karyawan dan organisasi sehingga perlu dipelihara dengan baik keberadaannya dari waktu ke waktu dan berupaya agar terus ditingkatkan sejalan dengan dinamika individu dan organisasi itu sendiri. Kepuasan kerja yang tinggi akan berdampak pada kondisi kerja yang lebih positif juga dinamis, sehingga memberi keuntungan yang nyata untuk organisasi maupun karyawan itu sendiri.

Dari hasil studi literatur, belum ditemukan penelitian yang menguji pengaruh kepuasan kerja terhadap komitmen karyawan pada organisasi yang bergerak di bidang kantor hukum, khususnya pada konteks Jakarta, Indonesia. Umumnya penelitian dilakukan pada organisasi bisnis atau organisasi pemerintahan. Pengelolaan sebuah kantor hukum sendiri cukup berbeda dengan pengelolaan organisasi bisnis maupun pemerintahan. Terutama pada struktur penjenjangan jabatan yang berbeda dikarenakan lebih menekankan pada tingkatan kemampuan dari profesi ahli hukum, yaitu mulai dari yang tertinggi adalah managing partner hingga yang terendah yaitu staff. Perlu diketahui bagaimana sebaiknya organisasi di bidang hukum mengelola dan memperlakukan karyawannya, agar mereka memiliki kepuasan dan komitmen yang tinggi terhadap pencapaian sasaran organisasi. Apakah pendekatan manajemen sumberdaya manusia yang dilakukan sama dengan yang diterapkan pada jenis organisasi lainnya? Ataukah perlu dilakukan pendekatan manajemen sumberdaya manusia yang berbeda? Dengan demikian penelitian ini bertujuan untuk:

1. Menguji secara kuantitatif pengaruh kepuasan kerja terhadap komitmen karyawan pada organisasi yang bergerak di bidang Kantor Hukum.

2. Mengidentifikasi tingkat kepuasan kerja dan komitmen karyawan pada organisasi Kantor Hukum yang menjadi obyek studi dan faktor-faktor yang dominan membentuk kepuasan kerja serta komitmen yang tinggi dari karyawan.

3. Menetapkan implikasi teoritis dan manajerial berdasarkan temuan yang didapat pada tujuan penelitian pertama dan kedua.

\section{Komitmen Karyawan pada Organisasi}

Komitmen karyawan pada organisasi adalah suatu keadaan dimana seorang karyawan memihak pada suatu organisasi tertentu dan tujuan-tujuannya dan keinginannya untuk mempertahankan keanggotaan dalam organisasi tersebut (Robbins \& Judge, 2012). Jadi, keterlibatan pekerjaan yang tinggi berarti memihak pada pekerjaan tertentu seorang individu, sementara komitmen karyawan pada organisasi yang tinggi berarti memihak organisasi yang merekrut individu tersebut. Komitmen karyawan pada organisasi, secara tidak langsung menyatakan sebuah tujuan untuk tetap melakukan suatu rangkaian tindakan sehingga organisasi/perusahaan berupaya untuk mengembangkan komitmen karyawannya untuk mencapai kestabilan karena diyakini bahwa karyawan yang berkomitmen akan bekerja lebih keras dan melangkah lebih jauh untuk mencapai tujuan organisasi (Allen \& Meyer, 1990).

Komitmen karyawan pada organisasi menurut Allen \& Meyer (1990) adalah komitmen dalam berorganisasi sebagai suatu konstruk psikologis yang merupakan karakteristik hubungan anggota 
organisasi dengan organisasinya dan memiliki implikasi terhadap keputusan individu untuk melanjutkan keanggotaannya dalam berorganisasi. Menurut Mowday, Porter \& Steers (1982) komitmen organisasi sebagai kekuatan relatif dari identifikasi individu dan keterlibatannya dengan organisasi kerja. Menurut Mitchell (1982) memandang komitmen organisasi sebagai suatu orientasi nilai terhadap kerja yang menunjukkan bahwa individu sangat memikirkan pekerjaannya, pekerjaan memberikan kepuasan hidup dan pekerjaan memberikan status bagi individu.

Komitmen organisasi juga membahas kedekatan karyawan terhadap organisasi dimana mereka berada dan bagaimana komitmen secara langsung merefleksikan keterlibatan secara kuat antara karyawan dan organisasi. Keterlibatan ini dipengaruhi oleh seberapa besar pekerjaan yang dibebankan pada karyawan sesuai dengan harapan mereka (Babakus et al, 1996). Menurut Davis \& Newstorm (2002) bahwa komitmen organisasional merupakan tingkat dimana individu memihak dan ingin secara berkelanjutan berpartisipasi aktif dalam organisasi yang tercermin melalui karakteristik-karakteristik sebagai berikut: (1) Adanya keyakinan kuat dan penerimaan atas nilai dan tujuan organisasi. (2) Kesediaan untuk mengusahakan yang terbaik bagi organisasi. (3) Adanya keinginan yang pasti untuk bertahan dalam organisasi.

Allen \& Meyer (1990) mengemukakan terdapat tiga dimensi dari komitmen karyawan pada organisasi.

1. Komitmen Afektif (Affective Commitment). Komitmen ini mengacu pada hubungan emosional anggota terhadap organisasi. Orang-orang ingin terus bekerja untuk organisasi tersebut karena mereka sependapat dengan tujuan dan nilai dalam organisasi tersebut. Orang-orang dengan tingkat komitmen afektif yang tinggi memiliki keinginan untuk tetap berada di organisasi karena mereka mendukung tujuan dari organisasi tersebut dan bersedia membantu untuk mencapai tujuan tersebut.

2. Komitmen Kelanjutan (Continuance Commitment). Komitmen ini mengacu pada keinginan karyawan untuk tetap tinggal di organisasi tersebut karena adanya perhitungan atau analisis tentang untung dan rugi dimana nilai ekonomi yang dirasa dari bertahan dalam suatu organisasi dibandingkan dengan meninggalkan organisasi tersebut. Semakin lama karyawan tinggal dengan organisasi mereka, semakin mereka takut kehilangan apa yang telah mereka investasikan di dalam organisasi selama ini.

3. Komitmen Normatif (Normative Commitment). Komitmen ini mengacu pada perasaan karyawan dimana mereka diwajibkan untuk tetap berada di organisasinya karena adanya tekanan dari yang lain. Karyawan yang memiliki tingkat komitmen normatif yang tinggi akan sangat memperhatikan apa yang dikatakan orang lain tentang mereka jika mereka meninggalkan organisasi tersebut. Mereka tidak ingin mengecewakan atasan mereka dan khawatir jika rekan kerja mereka berpikir buruk terhadap mereka karena pengunduran diri tersebut. 
Allen \& Meyer (1990) mengelompokkan faktor-faktor yang mempengaruhi komitmen karyawan pada organisasi ke dalam tiga kategori, yaitu:

1. Karakteristik Pribadi Individu. Faktor ini terbagi kedalam 2 (dua) variabel, yaitu variabel demografis dan variabel disposisional. Variabel demografis mencakup gender, usia, status pernikahan, tingkat pendidikan, dan lamanya seseorang bekerja pada suatu organisasi. Sedangkan variabel disposisional mencakup kepribadian dan nilai yang dimiliki anggota organisasi. Variabel disposisional ini memiliki hubungan yang lebih kuat dengan komitmen berorganisasi, karena adanya perbedaan pengalaman masing-masing anggota dalam organisasi tersebut.

2. Karakteristik Organisasi. Yang termasuk dalam karakteristik organisasi itu sendiri yaitu: struktur organisasi, desain kebijaksanaan dalam organisasi dan bagaimana kebijaksanaan organisasi tersebut disosialisasikan.

3. Pengalaman Organisasi. Sedangkan pengalaman berorganisasi tercakup ke dalam kepuasan dan motivasi anggota organisasi selama berada dalam organisasi, perannya dalam organisasi tersebut, dan hubungan antara anggota organisasi dengan supervisor atau pimpinannya.

Keberhasilan pengelolaan perusahaan sangat ditentukan oleh keberhasilan dalam mengelola sumber daya manusia. Seberapa besar komitmen karyawan terhadap perusahaan tempat mereka bekerja, sangatlah menentukan perusahaan itu dalam mencapai tujuannya. Sehingga dalam menjalankan proses pada organisasional, karyawan diharapkan mampu berorientasi pada tujuan bersama perusahaan. Komitmen organisasi yang kuat akan mendorong setiap karyawan berusaha keras untuk mencapai tujuan organisasi.

\section{Kepuasan Kerja}

Kepuasan kerja merupakan topik yang menarik untuk selalu dibahas dan memiliki variabel yang paling banyak dipelajari dalam penelitian setiap perilaku organisasi. Banyak alasan yang mengharuskan organisasi memperhatikan kepuasan kerja karyawan sebagai landasan bagaimana perusahaan atau organisasi itu sendiri akan terus bertumbuh. Kepuasan kerja merupakan suatu sikap umum terhadap pekerjaan seseorang, selisih antara banyaknya ganjaran yang diterima seorang pegawai dan banyaknya yang mereka yakini apa yang seharusnya mereka terima dan sikap umum seorang individu terhadap pekerjaannya, seorang dengan tingkat kepuasan kerja tinggi menunjukkan sikap yang positif terhadap pekerjaan itu, seseorang yang tidak puas dengan pekerjaannya akan menunjukkan sikap negatif terhadap pekerjaan itu (Robbins \& Judge, 2012). Kepuasan kerja karyawan merupakan faktor yang dianggap penting, karena dapat mempengaruhi jalannya sebuah organisasi dan merupakan suatu petunjuk bahwa karyawan memiliki perasaan senang dalam menjalankan pekerjaannya. Bagi organisasi, kepuasan kerja karyawan harus mendapat perhatian dan pemenuhan yang mana dalam hal ini menjadi tugas pimpinan organisasi sedangkan bagi karyawan, kepuasan kerja merupakan faktor individu dan sarana untuk mencapai pendukung kerja. 
Definisi yang paling banyak digunakan adalah "sebuah keadaan positif (emosi) yang dihasilkan dari penilaian pekerjaan atau pengalaman kerja seseorang" (Judge et al, 2001). Jadi kepuasan kerja adalah hal yang berbeda untuk orang yang berbeda, karena orang dipengaruhi berbagai faktor berbeda termasuk karakteristik, kebutuhan, nilai, perasaan, dan harapan pribadi. Hal ini termasuk ke dalam kehidupan berorganisasi dimana kepuasan kerja mempengaruhi faktor-faktor seperti lingkungan kerja, karakteristik pekerjaan, peluang bagi karyawan dalam bekerja.

Menurut Spector (1997) data kepuasan kerja sangat membantu dalam mengevaluasi emosi kesehatan dan kebugaran mental karyawan sehingga organisasi dapat menggunakan informasi tersebut untuk meningkatkan strukturnya. Definisi lain dari konsep kepuasan kerja adalah "sejauh mana orang suka atau tidak suka/tidak puas dengan pekerjaan mereka”. Bahkan, ketidakpuasan dalam pekerjaan dapat mengurangi kerja individu dan menyebabkan beberapa efek negatif seperti produktivitas rendah, absensi, dan berhenti dari pekerjaan. Spector (1997) membangun instrumen pengukuran kepuasan kerja Job Satisfaction Survey (JSS) yang menggunakan 9 (sembilan) dimensi kepuasan kerja seperti yang dikemukakan di atas yaitu: gaji, promosi, tunjangan tambahan, atasan, penghargaan dari perusahaan, peraturan prosedur kerja, rekan kerja, sifat pekerjaan, dan komunikasi dalam perusahaan.

Sedangkan Luthans (2006) mengemukakan, ada 6 (enam) faktor penting yang mempengaruhi kepuasan kerja karyawan yaitu:

1. Pekerjaan itu sendiri. Sejauh apa karyawan memandang pekerjaannya sebagai pekerjaan yang menarik, memberikan kesempatan untuk belajar, dan peluang untuk menerima tanggung jawab.

2. Upah atau gaji. Hal ini merupakan jumlah balas jasa finansial yang diterima karyawan dan tingkat dimana hal ini dipandang sebagai suatu hal yang adil dalam organisasi.

3. Kesempatan untuk kenaikan jabatan dalam jenjang karir.

4. Supervisi, yang merupakan kemampuan supervisor untuk memberikan bantuan secara teknis maupun memberikan dukungan

5. Rekan kerja, merupakan suatu tingkatan dimana rekan kerja memberikan dukungan

6. Kondisi kerja. Apabila kondisi kerja karyawan baik (bersih, menarik, dan lingkungan kerja yang menyenangkan) akan membuat mereka mudah menyelesaikan pekerjaannya.

Setiap individu memiliki tingkat kepuasan yang berbeda-beda sesuai dengan sistem nilai-nilai yang berlaku dari masing-masing individu itu sendiri. Banyak hal yang disebabkan oleh hal ini seperti contohnya karena perbedaan dari masing-masing individu atau karyawan itu sendiri. Dapat dikatakan kepuasan kerja merupakan generalisasi sikap-sikap yang didasarkan atas aspek-aspek pekerjaan yang bermacam-macam. Seperti halnya kebutuhan psikologi, rekan kerja, lingkungan kerja, dan banyak hal lainnya termasuk atasan. Semakin banyak aspek yang tidak sesuai dengan keinginan karyawan atau individu maka akan semakin tinggi ketidakpuasan seseorang. 


\section{Model dan Hipotesis Penelitian}

Berdasarkan konsep, teori serta hasil penelitian di atas maka dihasilkan model dan hipotesis penelitian yang akan diuji sebagai berikut.

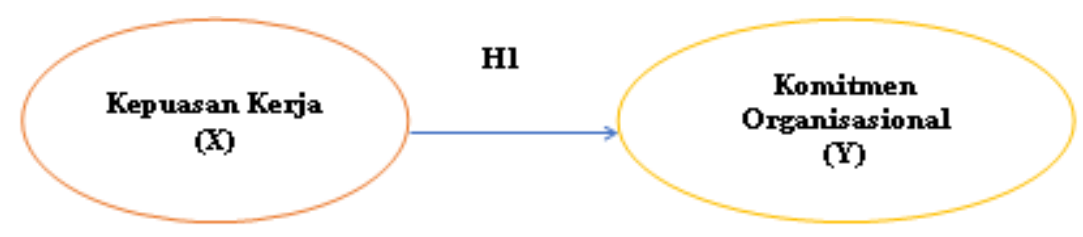

\section{Gambar 1. Model Penelitian}

H0 : Tidak terdapat pengaruh kepuasan kerja terhadap komitmen organisasional karyawan pada Kantor Hukum

H1: Terdapat pengaruh kepuasan kerja terhadap komitmen organisasional karyawan pada Kantor Hukum

\section{METODOLOGI PENELITIAN}

Penelitian ini menggunakan pendekatan kuantitatif, dengan jenis penelitian deskriptif. Penelitian dilakukan secara kuantitatif dengan melakukan pengumpulan data melalui metode sensus yang dilakukan terhadap seluruh karyawan yang bekerja di sebuah organisasi yang bergerak pada bidang kantor hukum yang berlokasi di Jakarta. Kantor hukum ini merupakan satu dari 30 kantor hukum modern di Indonesia yang secara legal terdaftar (hukumonline.com). Pemilihan kantor hukum ini sebagai obyek studi didasarkan pada aspek kemudahan karena salah satu peneliti bekerja pada kantor hukum tersebut. Populasi yang diteliti adalah seluruh karyawan yang bekerja pada organisasi tersebut. Terpilih 153 (seratus lima puluh tiga) karyawan sebagai sampel penelitian yang memenuhi kriteria berikut ini: (1) aktif bekerja di kantor hukum yang menjadi obyek studi, (2) usia minimal 20 tahun, (3) memiliki pendidikan formal minimal setara tingkat menengah atas, dan (4) minimal tiga bulan masa kerja (sudah lolos masa percobaan).

Dalam penelitian ini, variabel kepuasan kerja diukur dengan menggunakan instrumen yang dibangun oleh Spector (1997) yaitu Job Satisfaction Survey (JSS) yang mengukur 9 (sembilan) dimensi kepuasan kerja seperti yang telah dikemukakan pada bab tentang teori, yaitu: gaji, promosi, tunjangan tambahan, atasan, penghargaan dari perusahaan, peraturan prosedur kerja, rekan kerja, sifat pekerjaan, dan komunikasi dalam perusahaan. Terdapat 36 (tiga puluh enam) pertanyaan positif- negatif untuk mengukur sembilan dimensi, dengan 5 (lima) skala respon, mulai dari 1 (satu) yang artinya sangat tidak setuju, hingga 5 (lima) yang artinya sangat setuju. Sedangkan variabel komitmen organisasional diukur menggunakan instrumen The Organizational Commitment Questionnaire atau OCQ yang dirancang oleh Allen dan Meyer (1990). Kuesioner Allen dan Meyer terdiri dari 18 pernyataan yang mengukur tiga dimensi komitmen terhadap organisasi, masing-masing diukur berdasarkan enam pernyataan menggunakan skala likert dengan alternatif respon mulai dari 1 (satu) yaitu sangat tidak setuju sampai skala 5 (lima) yaitu sangat setuju. Pernyataan-pernyataan tersebut digunakan untuk mengidentifikasi 
tiga dimensi utama dari komitmen terhadap organisasi, yaitu: (1) affective commitment, (2) continuance commitment, dan (3) normative commitment.

Data yang didapat kemudian diolah menggunakan SPSS untuk melakukan sejumlah uji yang meliputi: uji validitas dan reliabilitas, uji asumsi klasik dan uji hipotesis (uji t). Selain itu juga dilakukan analisis deskriptif untuk melihat kecenderungan persepsi dari responden. Untuk analisis deskriptif, akan dilakukan penghitungan nilai rata-rata untuk: (a) Keseluruhan pernyataan yang menggambarkan faktor kepuasan kerja dan komitmen organisasional; dan (b) per pernyataan pada kuesioner. Hasil olah data kuesioner yang sudah dilakukan berdasarkan tahapan diatas, selanjutnya akan diinterpretasi menggunakan nilai norma yang ditetapkan oleh Hague (1993), dengan ketentuan sebagai berikut:

1. Jika nilai rata-rata persepsi karyawan adalah $\geq 80 \%$ skala yang digunakan (misal $\geq 4$ dari skala 5), maka secara umum responden menyatakan sangat setuju dengan pernyataan yang diberikan atau dengan kata lain kondisi perusahaan untuk variabel terkait dinilai sudah sangat baik (good practice)

2. Jika nilai rata-rata persepsi karyawan adalah $70 \%$ - <80\% skala yang digunakan (misal: $3,5-$ 3,9 dari skala 5), maka responden menyatakan bahwa mereka setuju dengan pernyataan yang diberikan atau dengan kata lain kondisi perusahaan untuk variabel terkait dinilai sudah cukup baik namun membutuhkan perbaikan minor/kecil (needs minor development).

3. Jika nilai rata-rata persepsi karyawan adalah $60 \%$ - $<70 \%$ skala yang digunakan (misal: 3,0 3,4 dari skala 5), maka responden menyatakan bahwa mereka kurang setuju dengan pernyataan yang diberikan atau dengan kata lain kondisi perusahaan untuk variabel terkait dinilai belum baik dan membutuhkan perbaikan mayor atau perbaikan besar (needs major improvement).

4. Jika nilai rata-rata persepsi karyawan adalah $<60 \%$ skala yang digunakan (misal: $<3,0$ dari skala 5), maka responden menyatakan bahwa mereka tidak setuju dengan pernyataan yang diberikan atau dengan kata lain kondisi perusahaan untuk variabel terkait dinilai tidak baik dan membutuhkan perbaikan menyeluruh (total improvement).

Berdasarkan hasil olah data, dilakukan diskusi dan pembahasan yang mencakup implikasi teoritis dan praktis. Secara akademik, akan dihasilkan implikasi teoritis berupa kesimpulan apakah temuan memperkuat, melengkapi atau bertentangan dengan hasil penelitian sebelumnya. Secara maajerial, akan dihasilkan rekomendasi umum terkait apa tindakan yang perlu dilakukan untuk meningkatkan kepuasan kerja dan komitmen organisasional karyawan berdasarkan temuan yang didapat. Selain itu juga akan dikemukakan keterbatasan penelitian serta saran penelitian lanjutan.

\section{HASIL DAN PEMBAHASAN}

Dari hasil pengolahan data diperoleh diperoleh nilai t hitung dan tingkat signifikansi pengaruh variabel Kepuasan Kerja terhadap variabel Komitmen Organisasional sebagaimana dapat dilihat pada Tabel 1. 


\begin{tabular}{|c|c|c|c|c|c|c|}
\hline \multicolumn{7}{|c|}{ Tabel 1. Hasil Uji t } \\
\hline \multirow[b]{2}{*}{ Model } & & \multicolumn{2}{|c|}{ Unstandardized Coefficients } & $\begin{array}{l}\text { Standardized } \\
\text { Coefficients }\end{array}$ & \multirow[b]{2}{*}{$\mathrm{t}$} & \multirow[b]{2}{*}{ Sig. } \\
\hline & & B & Std. Error & Beta & & \\
\hline 1 & $($ ConstanT) & -8.782 & 4.522 & & -1.942 & .054 \\
\hline & X_KepuasanKerja & .497 & .029 & .812 & 17.101 & .000 \\
\hline
\end{tabular}

a. Dependent Variable : Y_Komitmen

Sumber : Data diolah oleh peneliti

Diperoleh nilai signifikansi $0,000<0,05$ dan nilai $t_{\text {hitung }} 17,101>t_{\text {tabel }} 1,97569$ yang berarti dapat disimpulkan bahwa Hipotesis 1 diterima. Hal ini menunjukkan terdapat pengaruh yang signifikan dari variabel X (Kepuasan Kerja) terhadap variabel Y (Komitmen Organisasional). Sedangkan dari hasil analisis deskriptif diperoleh nilai rata-rata keseluruhan respon dari responden sebesar 4,19 (83,81\% dari skala 5) untuk variabel kepuasan kerja dan 3,71 (74,28\% dari skala 5) untuk variabel komitmen organisasional. Mengacu pada Hague (1993), hal ini menunjukkan bahwa secara keseluruhan Kepuasan Kerja berada pada kategori sangat baik dan Komitmen Organisasional berada pada kategori baik berdasarkan persepsi responden (karyawan). Tabel 2 menunjukkan nilai rata-rata yang didapat untuk setiap dimensi yang ada pada masing-masing variabel.

Tabel 2. Skor Rata-rata Persepsi Responden atas Dimensi dari Variabel Kepuasan Kerja \& Komitmen Organisasional

\begin{tabular}{lccc}
\hline \multicolumn{1}{c}{ Variabel \& Dimensi } & $\begin{array}{c}\text { Skor Rata-Rata } \\
\text { (Dalam Angka) }\end{array}$ & $\begin{array}{c}\text { Skor Rata-Rata } \\
\text { (Dalam Persentase) }\end{array}$ & $\begin{array}{c}\text { Interpretasi } \\
\text { (Hague, 1993) }\end{array}$ \\
\hline KEPUASAN KERJA (X) & 4,19 & $87,52 \%$ & Sangat Baik \\
\hline Gaji & 4,21 & $84,23 \%$ & Sangat Baik \\
\hline Promosi & 3,97 & $79,38 \%$ & Baik \\
\hline Tunjangan tambahan & 4,10 & $81,96 \%$ & Sangat Baik \\
\hline Atasan & 3,93 & $78,59 \%$ & Baik \\
\hline Penghargaan dari perusahaan & 4,43 & $88,60 \%$ & Sangat Baik \\
\hline Peraturan prosedur kerja & 4,17 & $83,31 \%$ & Sangat Baik \\
\hline Rekan kerja & 4,38 & $87,67 \%$ & Sangat Baik \\
\hline Sifat pekerjaan & 4,38 & $87,52 \%$ & Sangat Baik \\
\hline Komunikasi & 4,35 & $86,93 \%$ & Sangat Baik \\
\hline KOMITMEN ORGANISASIONAL $(\mathbf{Y})$ & 3,71 & $74,28 \%$ & Baik \\
\hline Komitmen Afektif & 3,61 & $72,22 \%$ & Baik \\
\hline Komitmen Normatif & 3,80 & $76,06 \%$ & Baik \\
\hline Komitmen Kontinuans & 3,73 & Baik \\
\hline \multicolumn{2}{r}{ : Data diolah oleh peneliti } \\
\end{tabular}

\section{KESIMPULAN DAN SARAN}

Secara teoritis, implikasi dari temuan penelitian ini menunjukkan adanya dukungan atas hasil penelitian terdahulu yang menunjukkan bahwa kepuasan kerja memiliki pengaruh signifikan terhadap komitmen organisasional. Hasil penelitian ini mendukung sejumlah hasil penelitian di dalam dan luar negeri, yang dilakukan pada berbagai bidang organisasi yang berbeda, yaitu: penelitian Bashir \& Gani (2019) terhadap 396 dosen di India; penelitian Eliyana, Ma'arif \& Muzakki (2019) terhadap 30 manajer menengah dari sebuah perusahaan yang bergerak pada bidang pelabuhan di Indonesia; penelitian Dalkrani \& Dimitriadis (2018) terhadap 439 karyawan yang bekerja pada perusahaan swasta dari 
berbagai industri di Yunani; penelitian Shah et al (2014) terhadap karyawan profesional yang bekerja pada bidang IT di Pakistan; penelitian Imam, Raza \& Ahmed (2014) yang dilakukan terhadap karyawan bank dari berbagai kota di Pakistan; penelitian Pangestu (2014) pada sebuah bank di Semarang Indonesia; dan penelitian Akbar, Hamid \& Djudi (2016) terhadap 298 karyawan tetap dari PG Kebon Agung Malang Indonesia.

Sedangkan secara praktis, dengan ditemukannya pengaruh yang signifikan dari kepuasan kerja terhadap komitmen organisasional maka diharapkan perusahaan lebih memperhatikan dan meningkatkan kepuasan kerja karyawan, yang pada akhirnya diharapkan meningkatkan komitmen karyawan dalam pencapaian tujuan organisasi. Pada Tabel 2, terlihat bahwa untuk tiga dimensi komitmen karyawan terhadap organisasi memiliki kondisi yang hampir sama yaitu berada pada kategori Baik.

Untuk meningkatkan komitmen organisasional karyawan hingga kategori Sangat Baik, organisasi perlu meningkatkan kepuasan kerja karyawannya. Dari tabel di atas ditunjukkan tiga dimensi kepuasan kerja yang terutama menyebabkan kepuasan kerja karyawan di kantor hukum yang menjadi obyek studi secara berurutan adalah: (1) penghargaan dari perusahaan, (2) rekan kerja, dan (3) sifat pekerjaan. Responden menyebutkan bahwa penghargaan perusahaan atas pekerjaan yang dilakukan dan imbalan yang diberikan, rekan kerja yang kompeten, serta sifat pekerjaan yang berarti dan membanggakan merupakan aspek yang ada dan disediakan di organisasi, yang membuat mereka mengalami kepuasan dalam bekerja. Secara manajerial, implikasi dari temuan ini adalah organisasi dapat mempertahankan atau meningkatkan kepuasan kerja dengan cara mempertahankan atau memperkuat faktor-faktor ini. Cara lainnya adalah dengan meningkatkan aspek lainnya, terutama yang skor persepsinya masih rendah. Terdapat dua dimensi dengan skor kurang dari 4,00, yaitu: (1) promosi dan (2) atasan. Berdasarkan masukan responden, hal yang perlu diperbaiki dari kedua dimensi tersebut adalah kesempatan promosi yang memuaskan dan atasan yang bertindak adil.

Dikarenakan penelitian ini baru didasarkan pada studi di satu organisasi kantor hukum, maka untuk mendapatkan generalisasi temuan, perlu dilakukan penelitian serupa pada sejumlah organisasi lainnya yang bergerak di bidang yang sama. Perlu juga dilakukan pengukuran berdasarkan demografi responden, misalnya dengan memfokuskan penelitian pada karyawan inti (profesional di bidang hukum). 


\section{DAFTAR PUSTAKA}

Akbar, F. H., Hamid, D. dan Djudi, M. (2016). Pengaruh Kepuasan Kerja Terhadap Komitmen Organisasional Dan Kinerja Karyawan (Studi pada Karyawan Tetap PG Kebon Agung Malang). Jurnal Administrasi Bisnis: Vol. 38 No. 2.

Allen, N. J. dan Meyer, J. P. (1990). The Measurement and Antecedents of Affective, Continuance, and Normative Commitment to the Organization. Journal of Occupational Psychology, 63, 1-18.

Babakus, E., Cravens, D. W., Johnston, M. dan Moncrief, W. C. (1996). Examining the Role of Organizational Variable in The Salesperson Job Satisfaction Model. Journal of Personal Selling \& Sales Management Vol 16 issue 3.

Bashir, B. dan Gani, A. (2019). Testing the effects of job satisfaction on organizational commitment. Journal of Management Development. Emerald Publishing Limited 0262-1711. DOI 10.1108/JMD-07-2018-0210.

Dalkrani, M., dan Dimitriadis, E. (2018). The Effect of Job Satisfaction on Employee Commitment. International Journal of Business and Economic Sciences Applied Research, Volume 11, Issue 3.

Davis, K. dan Newstrom, J. W. (2002). Organizational Behavior: Human Behavior at Work $11^{\text {th }}$ ed. McGraw-Hill.

Eliyana, A., Ma'arif, S. dan Muzakki. (2019). Job satisfaction and organizational commitment effect in the transformational leadership towards employee performance. European Research on Management \& Business Economics Volume 25, Issue 3, September-December 2019, Pages 144150. https://doi.org/10.1016/j.iedeen.2019.05.001.

Hague, P. (1993). Questionnaire Design (Market Research). Kogan page.

Hammer, T. H. dan Avgar, A. (2005). The impact of union on job satisfaction, organizational commitment and turnover. Journal of Labour Research, Vol. 26, No. 2, pp. 241-266.

Hellriegel, D. dan Slocum, J. W. Jr. (2011). Organizational Behavior, Thirteenth. Cengage Learning.

Imam, A., Raza, A., dan Ahmed, M. (2014). Impact of Job Satisfaction on Organizational Commitment in Banking Sector Employees of Pakistan. Sci.Int (Lahore),26(1),419-423. 
Nahita, P. \& Saragih, E. H. (2021). Pengaruh Kepuasan Kerja terhadap Komitmen ....

Judge, T. A., Thoresen, C. J., Bono, J. E. dan Patton, G. K. (2001). The job satisfaction - job performance relationship: A qualitative and quantitative review. Psychological Bulletin, Vol. 127, No. 3, pp. 376-407.

Luthans, F. (2006). Perilaku Organisasi Ed 10. Penerbit Andi Jogjakarta.

Mathews, B. P. dan Shepherd, J. L. (2002). Dimensionality of Cook and Walls (1980) British organizational commitment scale revisited. Journal of Occupational and Organizational Psychology. 75 (3):369-375.

Mitchell, T. R. (1982). 'Motivation: New Directions for Theory, Research, and Practice', The Academy of Management Review, vol. 7, no. 1, pp. 80-88.

Mowday, R. T., Porter, L. W. dan Steers, R. M. (1982). Employee-Organizational Linkages: The Psychology of Commitment, Absenteeism and Turnover. New York: Academic Press.

Pangestu, A. A. (2014). "Pengaruh Kepuasan Kerja dan Komitmen Organisasi terhadap Kinerja Pegawai (Studi pada BNI KCU Semarang)”. Semarang: Universitas Diponegoro.

Robbins, P. S., dan Judge, A. T. (2012). Organizational behavior $\left(15^{\text {th }}\right.$ ed.). New Jersey: Pearson education, Inc.

Shah, F. T., Idrees, F., Imam, A., Khan, T. A., dan Mariyam, A. (2014). Impact of Job Satisfaction on Organizational Commitment in IT Sector Employees of Pakistan. ISSN: 2090-4274 Journal of Applied Environmental and Biological Sciences, 4(8)190-197, 2014. TextRoad Publication.

Spector. (1997). Job Satisfaction: Application, assessment, causes and consequences, Thousand Oaks, $C A$, Sage Publications, Inc.

Stup, R. E. (2006). Special Research Report: Human Resource Management and Dairy Employee Organizational Commitment. The Pennsylvania State University. 